\title{
GOOGLE CLASSROOM OR MOODLE? : UNIVERSITY STUDENT SATISFACTION IN DISTANCE LEARNING COMMUNICATION DURING COVID-19 PANDEMIC
}

\author{
Oleh: \\ Gunawan Wiradharma
}

\begin{abstract}
Distance learning is currently very much influenced by communication media. If in the past distance learning was done by module correspondence via postal delivery, now it is done using public internet facilities. Especially in the COVID-19 pandemic, almost all tertiary institutions utilize online learning for their lectures. There are two features that are commonly and commonly used as learning communication tools namely using Moodle and Google Classroom. The researcher uses the value expectation theory which is a derivative of the uses and gratification theory as a guideline for analyzing data and problems found in this study. Discussion Motives will include information, personal identity, integration and social interaction, and entertainment. Satisfaction will be achieved if the motive is fulfilled. The gap between satisfaction sought and satisfaction obtained will indicate differences in the level of satisfaction. The research method used is a comparative survey research. Data collection techniques through questionnaires were given to each of 116 Moodle and Google Classroom feature users in one of the public higher education in Jakarta. The results of this study were 232 PTN students were satisfied after using Moodle and Google Classroom features.
\end{abstract}

Keywords: Motive, Satisfaction, Google Classroom, Moodle.

\begin{abstract}
ABSTRAK
Pengajaran jarak jauh saat ini sangat dipengaruhi oleh media komunikasi. Saat ini dilakukan menggunakan fasilitas internet yang umum. Terlebih di masa pandemic COVID-19 ini, hamper semua perguruan tinggi memanfaatkan pembelajaran dalam jaringan untuk proses perkuliahannya. Ada dua fitur yang biasa dan umum digunakan sebagai sarana komunikasi pembelajaran yakni menggunakan Moodle dan Google Classroom. Peneliti menggunakan teori pengharapan nilai yang merupakan turunan dari teori uses and gratification sebagai pedoman untuk menganalisa data dan permasalahan yang ditemukan dalam penelitian ini. Metode penelitian yang digunakan adalah metode kuantitatif dengan jenis penelitian survei komparatif. Teknik pengumpulan data melalui kuesioner diberikan kepada masing-masing 116 pengguna fitur Moodle dan Google Classroom di salah satu perguruan tinggi negeri (PTN) di Jakarta. Hasil penelitian ini adalah 232 mahasiswa PTN merasa puas setelah menggunakan fitur Moodle dan Google Classroom.
\end{abstract}

Kata Kunci: Motif, Kepuasan, Google Classroom, Moodle

Universitas Terbuka, Gedung Fakultas III Lantai 1 \& 2, Jl. Pd. Cabe Raya, Pondok Cabe Udik, Pamulang, South Tangerang City, Banten 15418. gunawan.wiradharma@ecampus.ut.ac.id

Program Studi Ilmu Komunikasi - Institut Bisnis dan Informatika Kwik Kian Gie 


\section{INTRODUCTION}

In order to prevent the spread and transmission of various Covid-19s, the government has implemented policies, one of which is to reduce and eliminate Teaching and Learning Activities (KBM) in all campuses (both public and private) in Indonesia. This decision was considered very appropriate in order to reduce contact and avoid crowds during the Covid-19 pandemic. However, the government still urges all activities related to teaching and learning activities, such as lectures, discussions and other activities to continue by making various adjustments. One of the anticipations that was then put into effect was carrying out activities online (on the network) or learning online using the synchronous method: UmeetME, Webex, Zoom, Skype, Microsoft Teams, Googlemeet, and others. Apart from synchronous methods, asynchronous methods are also applied: eLisa, Elok, Elearning Pharmacy, WhatApps Group, and others. However, the teachers still pay attention to the continuation of the teaching and learning process and the achievement of the quality of learning that has been determined.

These various efforts were made to avoid and break the chain of the spread of Covid-19, which is currently shaking all countries in the world, including Indonesia. To anticipate the outbreak of the virus, currently the most effective way to do this is to do various activities at home including working from home, studying from home, not gathering and crowd-gathering, keeping a distance, always wearing masks and washing hands diligently. Even with these conditions, students are still encouraged to get learning materials effectively as usual so they won't miss the lecture material.

However, many students consider that teaching and learning activities using online methods / online methods like this are ineffective when compared to the usual methods. Not a few of them complained. In addition, the extravagant quota is also a problem, network constraints, the level of understanding online is more difficult, not all students and lecturers are ready for digital learning quickly, as well as other supporting facilities such as the availability of laptops.

As a social being, humans will never be satisfied forever. Every time human needs will continue to emerge and seem to have no limit. In addition, humans always need time and process to be able to adapt to new environments and activities. Therefore, it is understandable that many students complain about these new activities and methods because it is human nature.

In connection with this new method, namely online teaching and learning activities and processes, Uses and Gratification theory, it is revealed that the audience basically uses mass media based on certain motives. If human motives are fulfilled, then human needs will also be fulfilled. Those motives become a reference for someone to choose which media (cellphone) they will use. Every student must have their own reasons whether they should use the Moodle feature or prefer to use the Google Classroom feature. The reasons or motives can be different but they can also be the same depending on the individual who uses them.

All the satisfaction will be created after the various needs or motives of the teenagers are met. The theory used to measure the satisfaction level of adolescents is the Expectancy Values theory. This theory includes Gratification Sought and Gratification Obtained. Each feature certainly has its own level of satisfaction and weakness. It could be that the satisfaction regarding Moodle's features is greater, and vice versa, in fact, the satisfaction of Google Classroom features is higher. Therefore, the purpose of holding this research is to explain the difference in the level of satisfaction in using the Moodle and Google Classroom features among Communication Science students at one of the state universities (PTN) in Jakarta. 


\section{LITERATURE REVIEW}

Uses and Gratification theory focuses heavily on motive as an independent variable that influences media use. In this theory there is a variant called the Expectancy Values theory in the sense that someone's behavior is a function of the value of the expected results of an action. This theory contains the value of the goals to be achieved and the hope of successfully achieving these goals.

Regarding this concept, Palmgreen asks whether the motives of the audience have been fulfilled by the media and whether the audience is satisfied after using the media. To measure the concept of satisfaction, Gratification Sought (GS) and Gratification Obtained (GO) are used (Kriyantono, 2010: 210). This theory argues that someone will exert themselves to the world (media) based on their beliefs and evaluations of the world. Gratification Sought is the satisfaction that is sought or wanted by an individual (motive) when consuming certain types of media. Meanwhile, Gratification Obtained is the real satisfaction that a person gets after consuming a certain type of media.

According to Palmgreen, Gratification Sought is formed from one's beliefs about what the media can provide and from one's evaluation of the media's content. Meanwhile, Gratification Obtained questions more specific things, for example what is obtained after using the media from the start of certain events or rubrics (Kriyantono, 2010: 211).

Meanwhile, Littlejohn revealed that a person's beliefs about media content can be influenced by culture, one's institution, social conditions, and certain psychological variables. Then values are strongly influenced by cultural factors, social factors, needs, and also by psychological variables. Someone's satisfaction will be determined by these two factors, namely value and trust (Kriyantono, 2010: 211). In the following, the researcher presents the Expectancy Values model.

The indicators of gaps regarding whether someone is satisfied with the media according to Kriyantono (2010: 212), are:

1) If the average GS score is greater than the GO score, there will be a satisfaction gap because the needs obtained are less than the wants. 1. This means that the media fail to provide satisfaction to the audience.

2) If the average GS score is the same as the GO score, there will be no satisfaction gap because all the desired needs are met. This means that the media is quite successful in providing satisfaction to its audiences.

3) If the average GS score is smaller than the GO score, then the satisfaction gap is bigger than the desired needs. 1. This means that the media are very successful in providing satisfaction to their audiences.

The bigger the gap in the average score (mean score) that occurs, the media is more unsatisfactory to the audience. And conversely, the smaller the gap in the average score that occurs, the more satisfying the media is for the audience. Meanwhile, motive is the beginning of an individual using media. And evaluation is the final result to find out whether someone is satisfied with the use of the media. The purpose of this research is to find out whether the students of Public Higher Education Communication Studies in Jakarta are satisfied using the Moodle and Google Classroom features and how they are different. 


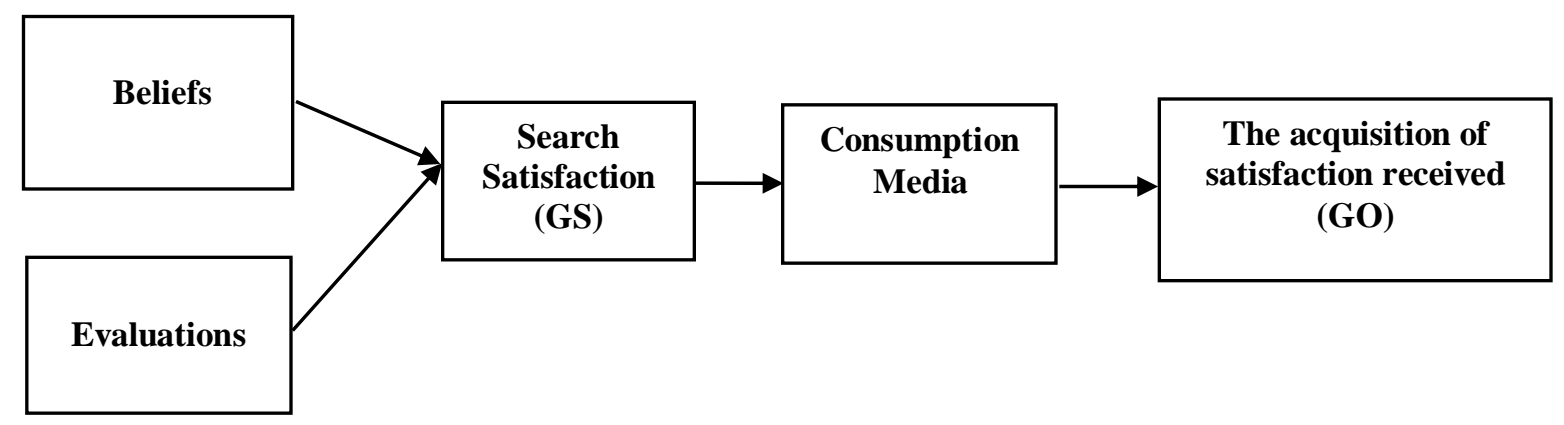

Figure 1

Expectancy Values Model

\section{RESEARCH METHODS}

This study uses a quantitative explanative survey research method that is comparative. Meanwhile, in this study the researchers involved a population of 553 people consisting of Communication Science students at State Universities in Jakarta. Then after being rounded off, the sample became 232 people. Of these 232, they were further divided into two groups, namely 116 respondents who used the Moodle feature and 116 respondents who used the Google Classroom feature. As for determining the number of samples and population, researchers used a purposive sampling method. Purposive sampling is a nonrandom sampling technique in which the researcher determines sampling by determining specific characteristics that are in accordance with the research objectives so that they are expected to answer the main research problems.

\section{RESULTS AND DISCUSSION}

In this study, researchers only focused on discussing two applications, namely the Moodle application and the Google Classroom application. First, the Moodle application used by students of the Communication Science Study Program at State Universities in Jakarta has the highest satisfaction with entertainment features, which is $3.86 \%$ and the lowest satisfaction is in the information feature, which is only $3.55 \%$. In the following, the researcher presents a table of the level of satisfaction of students of State Universities in Jakarta with the use of the Moodle application / feature. 
Table 1

Satisfaction Level Using Moodle Features

Aspect

Average Score

Motive

1. Guide for lecture administration info

2. Info guides outside of lectures

3. Guide to lecture assignments

4. A sense of peaceful discussion with friends

5. Peace with friends

INFORMATION

6. Considered cool

7. Keep up with technological

developments

8. Self Confidence

9. Get to know yourself

10. Get known in lectures

11. Do well in lectures

PERSONAL IDENTITY

12. Care about other people around

13. Help others

14. Discuss textbooks

15. Discuss assignment instructions from

the lecturer

\begin{tabular}{lccc} 
16. Take an active extracurricular role & 3.36 & 3.53 & $105,06 \%$ \\
\hline $\begin{array}{l}\text { 17. Familiar with friends } \\
\text { 18. Get to know other people }\end{array}$ & 3.61 & 3.49 & $96,68 \%$ \\
\hline $\begin{array}{l}\text { INTEGRATION AND SOCIAL } \\
\text { INTERACTION }\end{array}$ & 3.58 & 3.56 & $99,44 \%$ \\
\hline 19. Forget about problems & 3,55 & 3,56 & $100,28 \%$ \\
\hline 20. Relax & 3.80 & 3.61 & \\
\hline 21. Spending free time & 3.70 & 3.67 & $99,19 \%$ \\
\hline 22. Laugh out loud & 3.64 & 3.81 & $104,67 \%$ \\
\hline 23. Eliminate feelings of loneliness & 3.79 & 3.87 & $102,11 \%$ \\
\hline 24. Entertained & 4.07 & 3.93 & $96,56 \%$ \\
\hline 25. Happy & 3.99 & 4.06 & $101,75 \%$ \\
\hline ENTERTAINMENT & 3.95 & 4.04 & $102,28 \%$ \\
\hline
\end{tabular}

What is meant by the level of satisfaction is the percentage value of the distribution of satisfaction with the motive. The satisfaction level value is greater than $100 \%$, indicating that satisfaction is higher than motive or in other words, it means that students are satisfied. Meanwhile, the satisfaction level score is below
$100 \%$, indicating a lower level of satisfaction than the motive, or in other words, it means that students are not satisfied.

Broadly speaking, table 1 shows that the level of information satisfaction (100.57\%), personal identity $(100.85 \%)$, integrity and social interaction (100.28), and entertainment (100, 
$26 \%$ ) are all above $100 . \%$. Thus, it shows that the level of satisfaction with all aspects is satisfied / fulfilled. Meanwhile, of the 25 statement items, there were 12 statements with a satisfaction level below $100 \%$. Thus, it shows that there are several statement items from each aspect that are less or even unsatisfied.

Second, Google Classroom, not much different from Moodle, the Google Classroom application used by students of the Communication Science Study Program at State Universities in Jakarta also has the highest satisfaction with entertainment features, namely $3.58 \%$ and the lowest satisfaction is also found in features. information, namely only $3.53 \%$. In the following, the researcher presents a table of the level of satisfaction of students of State Universities in Jakarta with the use of the Google Classroom application / feature.

Table 2

Satisfaction Level of Using Google Classroom Features Aspect Average Score

\begin{tabular}{|c|c|c|c|}
\hline \multirow[t]{2}{*}{ Aspect } & \multicolumn{2}{|c|}{ Average Score } & \multirow{2}{*}{$\begin{array}{l}\text { Satisfaction } \\
\text { Level }\end{array}$} \\
\hline & Motive & Satisfaction & \\
\hline 1. Guide for lecture administration info & 3.38 & 3.44 & $101,78 \%$ \\
\hline 2. Info guides outside of lectures & 3.51 & 3.59 & $102,28 \%$ \\
\hline 3. Guide to lecture assignments & 3.57 & 3.56 & $99,72 \%$ \\
\hline $\begin{array}{l}\text { 4. A sense of peaceful discussion with } \\
\text { friends }\end{array}$ & 3.51 & 3.57 & $101,71 \%$ \\
\hline 5. Peace with friends & 3.57 & 3.51 & $98,32 \%$ \\
\hline INFORMATION & 3,51 & 3,53 & $100,57 \%$ \\
\hline 6. Considered cool & 3.56 & 3.58 & $100,56 \%$ \\
\hline $\begin{array}{l}\text { 7.Keep up with technological } \\
\text { developments }\end{array}$ & 3.51 & 3.56 & $101,43 \%$ \\
\hline 8. Self Confidence & 3.55 & 3.56 & $100,28 \%$ \\
\hline 9. Get to know yourself & 3.53 & 3.56 & $100,85 \%$ \\
\hline 10. Get known in lectures & 3.51 & 3.49 & $99,43 \%$ \\
\hline 11. Do well in lectures & 3.56 & 3.52 & $98,88 \%$ \\
\hline PERSONAL IDENTITY & 3,54 & 3,55 & $100,28 \%$ \\
\hline 12. Care about other people around & 3.51 & 3.55 & $101,14 \%$ \\
\hline 13. Help others & 3.60 & 3.62 & $100,56 \%$ \\
\hline 14. Discuss textbooks & 3.50 & 3.56 & $101,71 \%$ \\
\hline $\begin{array}{l}\text { 15. Discuss assignment instructions from } \\
\text { the lecturer }\end{array}$ & 3.53 & 3.55 & $100,57 \%$ \\
\hline 16. Take an active extracurricular role & 3.50 & 3.52 & $100,57 \%$ \\
\hline 17. Familiar with friends & 3.59 & 3.60 & $100,28 \%$ \\
\hline 18. Get to know other people & 3.57 & 3.51 & $98,32 \%$ \\
\hline $\begin{array}{lll}\text { INTEGRATION } & \text { AND } & \text { SOCIAL } \\
\text { INTERACTION } & & \end{array}$ & 3,54 & 3,56 & $100,57 \%$ \\
\hline 19. Forget about problems & 3.54 & 3.54 & $100 \%$ \\
\hline 20. Relax & 3.64 & 3.51 & $96,43 \%$ \\
\hline 21. Spending free time & 3.56 & 3.61 & $101,40 \%$ \\
\hline 22. Laugh out loud & 3.57 & 3.60 & $100,84 \%$ \\
\hline 23. Eliminate feelings of loneliness & 3.48 & 3.53 & $101,44 \%$ \\
\hline
\end{tabular}




\begin{tabular}{lccc} 
24. Entertained & 3.46 & 3.60 & $104,05 \%$ \\
\hline 25. Happy & 3.70 & 3.70 & $100 \%$ \\
\hline ENTERTAINMENT & 3,56 & 3,58 & $100,56 \%$ \\
\hline
\end{tabular}

What is meant by the level of satisfaction is the percentage value of the distribution of satisfaction with the motive. The satisfaction level value is greater than $100 \%$, indicating that satisfaction is higher than motive or in other words, it means that students are satisfied. Meanwhile, the satisfaction level score is below $100 \%$, indicating a lower level of satisfaction than the motive, or in other words, it means that students are not satisfied.

Broadly speaking, table 2 shows that the level of information satisfaction (100.57\%), personal identity $(100.28 \%)$, integrity and social interaction $(100.57 \%)$, and entertainment (100, $56 \%$ ) are all above $100 \%$. Thus, it shows that the level of satisfaction with all aspects is satisfied / fulfilled. Meanwhile, of the 25 statement items, there were 6 statements with a satisfaction level below $100 \%$. Thus, it shows that there are several statement items from each aspect that are less or even unsatisfied.

\section{Comparison of Moodle and Google Classroom Feature Usage Motives}

The hypotheses to be tested in this study are.

$\mathrm{H}^{0}$ : There is no difference regarding "motives" in the use of the Moodle and Google Classroom applications among PTN Communication Science students in Jakarta.

$\mathrm{H}^{1}$ : There are differences regarding "motives" in the use of the Moodle and Google Classroom applications among PTN Communication Science students in Jakarta.

Meanwhile, the level of significance is a $=0.05$

To test the hypothesis, the researcher used the mean difference test on the independent sample, namely the independent $\mathrm{T}$ test. The results can be seen in the following table:

Table 3

Result of Comparative Test of Use Motives

Moodle and Google Classroom features

\begin{tabular}{lrrccc}
\hline \multicolumn{1}{c}{ Motive } & Average & SD & t count & t table & p-value \\
\cline { 1 - 3 } Moodle & 3,63 & 0,1753 & 3,998 & $-1,970 \& 1,970$ & 0,000 \\
\cline { 1 - 3 } Google Classroom & 3,54 & 0,1755 & & & \\
\hline
\end{tabular}

Table 3 shows that the $\mathrm{T}$ test produces a $\mathrm{T}$ count of 3.998 with a probability value (p-value) of 0.000 . Meanwhile, the $\mathrm{T}$ table is generated from the formula $=\operatorname{TINV}(0.05,230)$ using Microsoft Excel, then the probability value of 0.05 and the degree of freedom is obtained from n-k (232-2 = 230). 


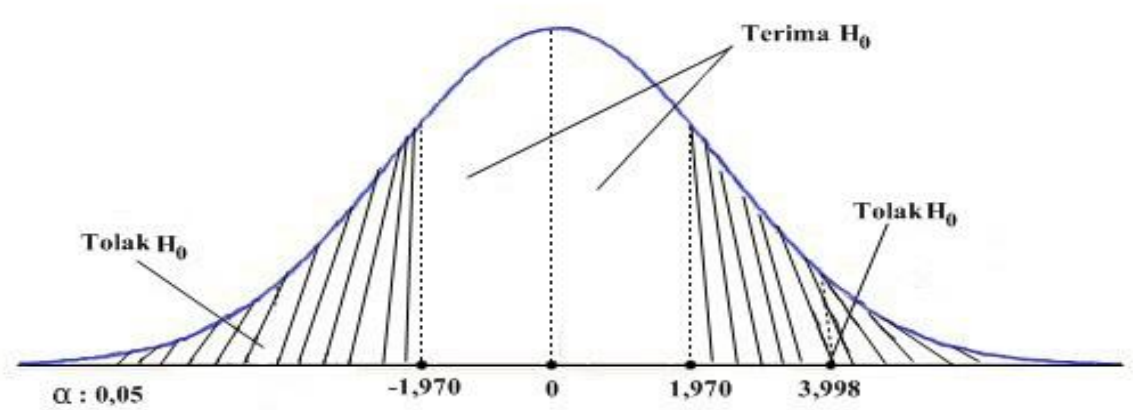

Figure 2

Usage Motive Comparison Chart Moodle and Google Classroom features

In graph 1 , it is found that the calculated $\mathrm{T}$ value (3.998) is greater than the $\mathrm{T}$ table $(-1.970$ and $1.970)$, thus the resulting conclusion is to reject $\mathrm{H}^{0}$ and accept $\mathrm{H}^{1}$. The p-value obtained $(0,000)$ is smaller than the specified significance value, namely 0.05 , so the result also rejects $\mathrm{H}^{0}$ and accepts $\mathrm{H}^{1}$. Thus, the resulting conclusion is that there is a significant difference between the motives for using the Moodle application and the Google Classroom application among PTN Communication Science students in Jakarta.

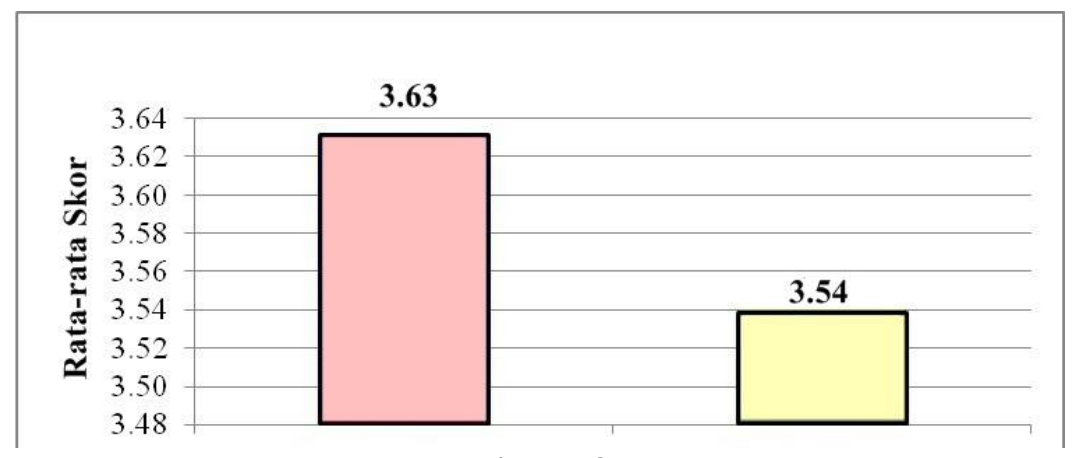

Figure 3

Mean Score Comparison Chart of Motives

In chart 1 , it can be seen that the average value of satisfaction in using the Moodle application (3.63) is higher when compared to the use of the Google Classroom application (3.54). Thus, it can be concluded that the motive for using the Moodle application for PTN Communication
Science students in Jakarta is higher when compared to the use of the Google Classroom application. This shows that the motive for using the Moodle application has more advantages than the Google Classroom application. 


\section{Comparison of the Satisfaction of Using Moodle and Google Classroom Features}

The hypotheses to be tested in this study are.

$\mathrm{H}^{0}$ : There is no difference regarding "satisfaction" in the use of the Moodle and Google Classroom applications among PTN Communication Science students in Jakarta.
$\mathrm{H}^{1}$ : There is a difference regarding "satisfaction" in using the Moodle and Google Classroom applications among PTN Communication Science students in Jakarta.

Meanwhile, the level of significance is $\mathrm{a}=0.05$

To test the hypothesis, the researcher used the mean difference test on the independent sample, namely the independent $\mathrm{T}$ test.

Table 4.

Results of Comparative Use Satisfaction Test

Moodle and Google Classroom features

\begin{tabular}{lrrccc}
\hline \multicolumn{1}{c}{ Motive } & Average & SD & t count & t table & p-value \\
\cline { 1 - 4 } Moodle & 3,65 & 0,1810 & 4.065 & $-1,970 \& 1,970$ & 0,000 \\
\cline { 1 - 3 } Google Classroom & 3,56 & 0,1525 & & & \\
\hline
\end{tabular}

Table 4 shows that the $\mathrm{T}$ test results in a $\mathrm{T}$ 0.05 and the degree of freedom is obtained from $\mathrm{n}-\mathrm{k}(232-2=230)$. count of 4.065 with a probability value ( $\mathrm{p}$-value) of 0.000. Meanwhile, the $\mathrm{T}$ table is generated from the formula $=\operatorname{TINV}(0.05,230)$ using Microsoft Excel, then the probability value of

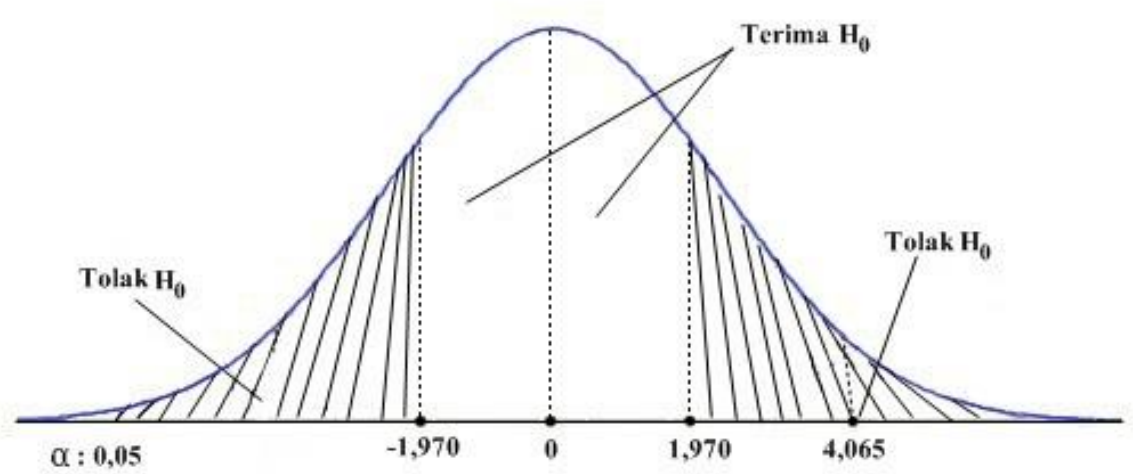

Figure 4.

Usage Satisfaction Comparison Graph Moodle and Google Classroom features 
Graph 2, it is found that the value of T count (4.065) is greater than $\mathrm{T}$ table (-1.970 and 1.970), thus the resulting conclusion is to reject $\mathrm{H}^{0}$ and accept $\mathrm{H}^{1}$. The p-value obtained $(0,000)$ is much smaller than the specified significance value, namely 0.05 , so the result also rejects $\mathrm{H}^{0}$ and accepts $H^{1}$. Thus, the resulting conclusion is that there is a significant difference between the satisfaction of using the Moodle application and the Google Classroom application among PTN Communication Science students in Jakarta.

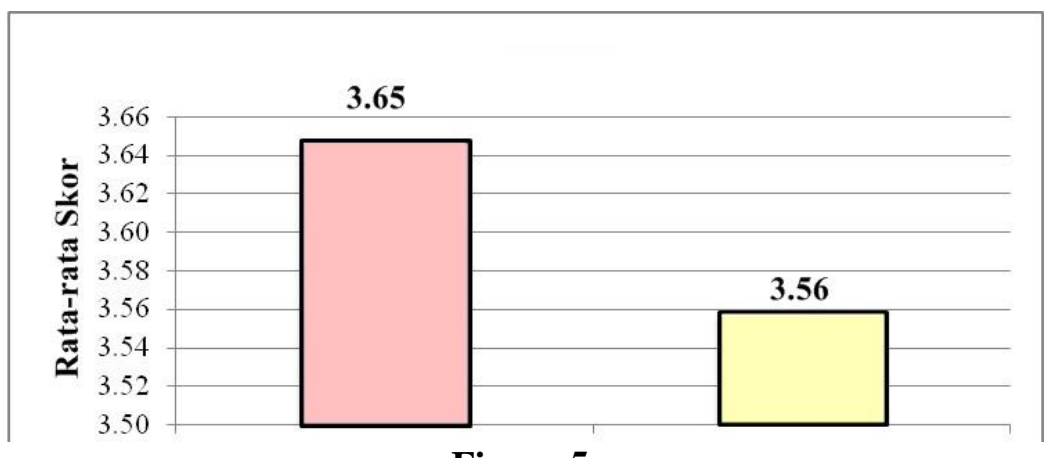

Figure 5.

Chart of Comparison of Mean Satisfaction Score

Chart 2, it can be seen that the average value of satisfaction using the Moodle application (3.65) is higher when compared to the use of the Google Classroom application (3.56). Thus, it can be concluded that the satisfaction of using the Moodle application for PTN Communication Science students in Jakarta is higher when compared to the use of the Google Classroom application. This shows that the satisfaction of using the Moodle application has more advantages than the Google Classroom application.

\section{Comparison of the Satisfaction Level of Using Moodle and Google Classroom Features}

The hypotheses to be tested in this study are.

$\mathrm{H}^{0}$ : There is no difference regarding the "level of satisfaction" in the use of the Moodle and Google Classroom applications among PTN Communication Science students in Jakarta.
$\mathrm{H}^{1}$ : There is a difference regarding the "level of satisfaction" in the use of the Moodle and Google Classroom applications among PTN Communication Science students in Jakarta.

Meanwhile, the level of significance is $a=0.05$

To test the hypothesis, the researcher used the mean difference test on the independent sample, namely the independent $\mathrm{T}$ test. The results can be seen in the following table: 
Table 5.

Results of Comparison of Usage Satisfaction Levels

Moodle and Google Classroom features

\begin{tabular}{lccccc}
\hline \multicolumn{1}{c}{ Motive } & Average & SD & t count & t table & $p$-value \\
\cline { 1 - 3 } Moodle & 100.58 & 5.90 & $-0,190$ & $-1,970 \& 1,970$ & 0,849 \\
\cline { 1 - 3 } Googlassroom & 100.73 & 6.37 & & & \\
\hline
\end{tabular}

Table 5, shows that the $\mathrm{T}$ test results in a $\mathrm{T}$ count of -0.190 with a probability value (p-value) of 0.849. Meanwhile, the $\mathrm{T}$ table is generated from the formula $=\operatorname{TINV}(0.05,230)$ using Microsoft Excel, then the probability value of
0.05 and the degree of freedom is obtained from $\mathrm{n}-\mathrm{k}(232-2=230)$.

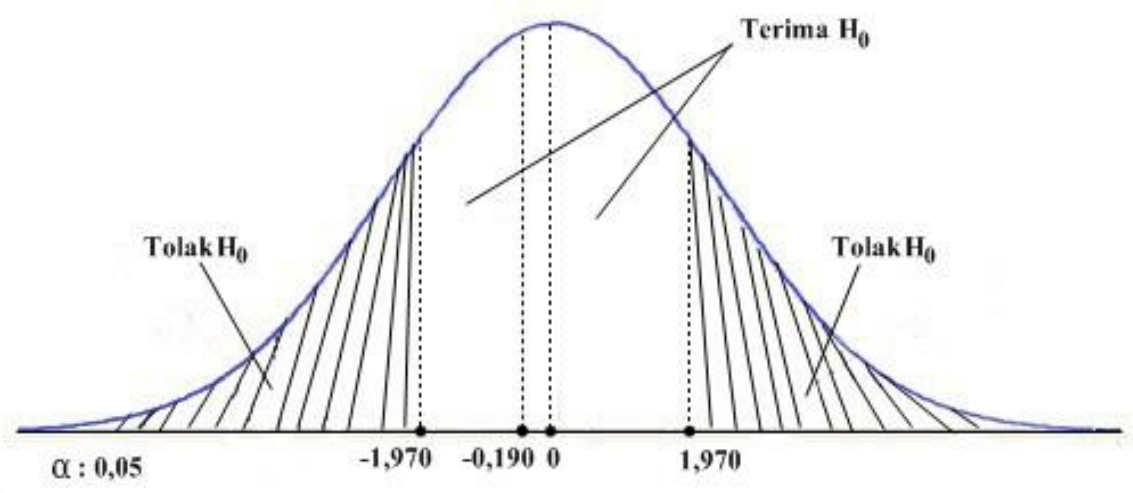

Figure 6.

Graph of Comparison of Usage Satisfaction Levels

Moodle and Google Classroom features

Graph 3, it is found that the calculated $\mathrm{T}$ value $(-0.190)$ is between the two $\mathrm{T}$ table values (-1.970 and 1.970), thus the resulting conclusion is to accept $\mathrm{H}^{0}$ and reject $\mathrm{H}^{1}$. The $\mathrm{p}$-value obtained $(0.849)$ is much greater than the specified significance value, namely 0.05 , so the results also accept $\mathrm{H}^{0}$ and reject $\mathrm{H}^{1}$.
Thus, the resulting conclusion is that there is no significant difference between the level of satisfaction using the Moodle application and the Google Classroom application among PTN Communication Science students in Jakarta. 


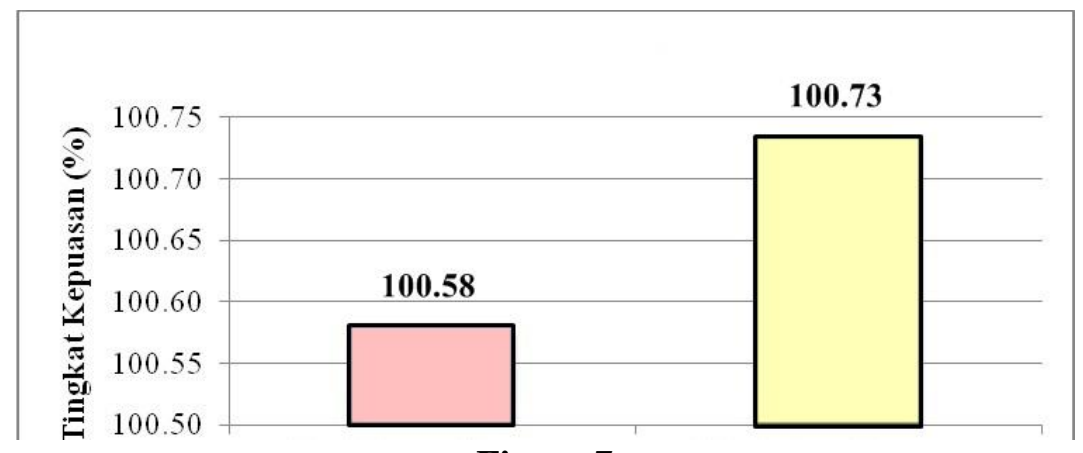

Figure 7

Chart of Comparison of Mean Satisfaction Score Score

Chart 3, it can be seen that the average value of the satisfaction level of using the Moodle application (100.58\%) is lower when compared to the use of the Google Classroom application (100.73\%). Thus, it can be concluded that the level of satisfaction with the use of the Moodle application for PTN Communication Science students in Jakarta is lower when compared to the use of the Google Classroom application. However, the difference between the two is not very significant.

From a total of 232 questionnaires distributed into two aspects, 116 questionnaires were distributed to Moodle application users and 116 questionnaires were distributed to those who used the Google Classroom application. Each application is dominated by women, $63.79 \%$ are users of the Moodle application and $75.86 \%$ are users of the Google Classroom application. In addition, respondents were dominated by students of class 2019 with a percentage of $39.66 \%$ users of the Moodle application and $51.72 \%$ of users of the Goodle Classroom application.

As for the results of the analysis of motives (gratification sought) in the use of the Moodle application, entertainment motives occupy the highest motive, namely $3.85 \%$, personal identity motives and integration and social interaction motives have the same value, namely $3,55 \%$, and information motives are the lowest that is $3.53 \%$.
Thus, the motive for entertainment in the Moodle application is the motif most sought after by PTN Communication Science students in Jakarta. Then, the results of the analysis of motives (gratification sought) in the use of the Google Classroom application, entertainment motives occupy the highest motive, namely $3.56 \%$, personal identity motives and integrity motives and social interactions have the same score, namely $3.54 \%$, and information Thus, the entertainment motive in the Google Classroom application is the motive that is most sought after by PTN Communication Science students in Jakarta.motives are motives. the lowest was $3.51 \%$.

The results of research on motives (GS) are reinforced by Gerungan's statement, he reveals that motive is an understanding that encompasses all movements, reasons or impulses in humans that cause humans to do something (Ardianto, 2007: 93). In other words, the entertainment motive is the biggest motive that is the reason or encouragement of PTN Communication Science students in Jakarta to use the Moodle application and the Google Classroom application.

Meanwhile, the results of the satisfaction analysis (gratification obtained) in the use of the Moodle application, the entertainment aspect occupies the highest level of satisfaction, namely $3.86 \%$, the aspect of personal identity occupies the second level of satisfaction, namely $3.58 \%$, 
the aspects of integration and social interaction rank third, namely $356 \%$, and the information aspect occupies the lowest satisfaction, namely $3.55 \%$. Thus, the entertainment aspect of the Moodle application is the aspect with the highest satisfaction score for PTN Communication Science students in Jakarta. Then, the results of the satisfaction analysis (gratification obtained) in the use of the Google Classroom application, the entertainment aspect still occupies the highest satisfaction, namely $3.58 \%$, followed by integration and social interaction aspects of $3.56 \%$, then personal identity aspects as much as $3.55 \%$ and aspects the lowest was the information aspect, namely $3.53 \%$. Thus, the entertainment aspect of the Google Classroom application is the aspect with the highest satisfaction value for PTN Communication Science students in Jakarta.

The results of research on satisfaction (GO) are then reinforced by West and Turner's statement, that satisfaction is related to need. Satisfaction will occur when there is a need or a desired motive. In this research, there is a need from every aspect and all of these aspects are satisfied. The biggest need or motive for these two applications is entertainment motive. And the greatest satisfaction that is achieved in these two applications is the entertainment aspect.

The results of the analysis regarding the level of satisfaction with the Moodle application are satisfied. Because the level of satisfaction is above $100 \%$ for all aspects, starting from the personal identity aspect of $100.85 \%$, followed by the information aspect of $100.57 \%$, then the integration and social interaction aspects of $100.28 \%$, and finally the information aspect of $100.26 \%$. Thus, the aspect of personal identity in the Moodle application is the aspect with the highest level of satisfaction for PTN Communication Science students in Jakarta.

In the Moodle application, all aspects have a motive (gratification sought) lower than satisfaction (gratification obtained), namely the information motive (3.53) is lower than information satisfaction (3.55), the personal identity motive (3.55) is lower of personal identity satisfaction (3.58), integration and social interaction motives (3.55) are lower than integration and social interaction satisfaction (3.56), and entertainment motives (3.85) are lower than entertainment satisfaction $(3,86)$. Thus, it shows that all needs including information, personal identity, social integration and interaction, and entertainment are fulfilled and satisfied when students of public higher education communication science in Jakarta use the Moodle application.

The results of the analysis regarding the level of satisfaction with the Google Classroom application are satisfied. Because the level of satisfaction is above $100 \%$ for all aspects, starting from the personal identity aspect of $100.28 \%$, the information aspect of $100.57 \%$, then the integration and social interaction aspect of $100.57 \%$, and finally the information aspect of $100.56 \%$. Thus, the information aspect as well as the integration and social interaction aspects of the Google Classroom application are the aspects with the most satisfactory level of satisfaction for PTN Communication Science students in Jakarta.

In the Google Classroom application, all aspects have motives (gratification sought) lower than satisfaction (gratification obtained), namely the information motive (3.51) is lower than information satisfaction (3.53), the personal identity motive (3.54) is more satisfaction with personal identity (3.55), integration and social interaction motives (3.54) lower than integration and social interaction satisfaction (3.56), and entertainment motive (3.56) lower than entertainment satisfaction $(3,58)$. Thus, it shows that all needs including information, personal identity, social integration and interaction, and entertainment are fulfilled and satisfied when students of public higher education communication science in Jakarta use the Google Classroom application.

The results of this research regarding the level of satisfaction are in line with the theory of expectancy values and are strengthened by 
Kriyantono's statement, that one indicator of the satisfaction gap is that if the mean GS score is smaller than the mean GO score, then there is a more satisfaction gap obtained than the desired need. In other words, the Moodle and Google Classroom applications satisfy their audiences, namely students of Public Higher Education Communication Studies in Jakarta.

The comparison of motives has a very significant difference between the motives for using the two applications. This is because $\mathrm{T}$ count (3.998) is greater than T table (-1.970) and (1.970), and the p-value (0.000) is smaller than the specified significance value, namely $(0.05)$. Thus, the motive for using the Moodle application (3.63) is higher than the use of the Google Classroom application (3.54), with a very significant difference. Then, the results of the comparison of satisfaction analysis, there is a very significant difference between the satisfaction of using the two applications. This is because the $\mathrm{T}$ count (4.065) is greater than (-1.970 and 1.970), and the p-value $(0.000)$ is smaller than the specified significance value (0.05). Thus, the satisfaction of using the Moodle application (3.65) is higher than the use of the Google Classroom application (3.56), with a very significant difference.

For the results of the comparative analysis of the satisfaction level of using these two applications, there is no significant difference between the satisfaction levels of using the two applications among PTN communication science students in Jakarta. This is because the T count ($0.190)$ is between the two T-table values $(-1.970$ and 1.970$)$ and the $p$-value $(0.849)$ is greater than the specified significance value, namely 0.05 . Then, the level of satisfaction using the Moodle application (100.58\%) is lower than using the Google Classroom application (100.73), although the difference is not too significant.

Thus, it can be concluded that in this study there is no difference in the level of satisfaction between using the Moodle application and using the Google Classroom application. Because, these two applications basically provide satisfaction in accordance with the methods and needs of PTN Communication Science students in Jakarta.

\section{CONCLUSION}

The motive of PTN Communication Science students in Jakarta, the highest average score in the use of the two online applications is entertainment motive, which is $3.85 \%$ for the Moodle application and $3.56 \%$ for the Google Classromm application. Then, after using the Moodle application, students expressed satisfaction and comfort with a percentage of $3.99 \%$ and satisfied to feel happy after using the Google Classroom application with a percentage of $3.70 \%$. This motif is the motive most sought after by PTN Communication Science students in Jakarta.

The highest average motive for using both Moodle and Goggle Classroom applications is the same, namely entertainment. However, after an overall comparative test was carried out regarding the motive variables, the results were significant differences between the two applications. In this case, the motive for using the Moodle application was $3.63 \%$ higher than the motive for using the Google Classroom application, namely $3.54 \%$, with a significant difference ( $p$-value $<0.05$ ).

Then, the results of the average value of motives and satisfaction include all aspects, namely information, personal identity, integration and social interaction, and entertainment, so the resulting average value of motives (gratification sought) is lower than satisfaction (gratification obtained) both in the Moodle application as well as in the Google Classroom application. Thus, these two applications can provide satisfaction to PTN Communication Science students in Jakarta because the mean score / average value of GS is smaller than the mean score / average GO score.

Both applications can be satisfying. However, after a comparative test was carried out on the satisfaction variable, the result was that 
there was a significant difference between the use of the two applications. In this case, satisfaction using the Moodle application was 3.65\% higher than satisfaction using the Google Classroom application, namely $3.56 \%$, with a p-value $<0.05$. Thus, the level of satisfaction using the Moodle application was $100.58 \%$ lower than the satisfaction using the Google Classroom application, which was $100.73 \%$.

However, after a comparative test was carried out regarding the level of satisfaction among students of PTN Communication Studies in Jakarta, this did not become a problem. Because, the results obtained from these tests are that there is no significant difference in the use of the two applications, namely p-value $>0.05$. Thus, both the Moodle application and the Google Classroom application both still provide satisfaction to PTN Communication Science students in Jakarta.

\section{REFERENCES}

Abrar, A.N. (2003), Teknologi Komunikasi Perspektif Ilmu Komunikasi, Yogyakarta: Lesfi.

Ardianto, Elvinaro, et al (2007), Komunikasi Massa Suatu Pengantar Edisi Revisi, Bandung: Simbiosa.

Kahn, Jordan (2014). "Google Classroom now available to all Apps for Education users, adds collaboration features". 9to5Google.

Koran Jakarta. (2012), Melesat karena Jadi Gaya Hidup, diakses 11 April 2012, (http://koranjakarta.com/index.php/detail/view01/ 84069.)

Kriyantono, Rachmat (2010), Teknik Praktis Riset Komunikasi: Disertai Contoh Praktis Riset Media, Public Relations, Advertising, Komunikasi Organisasi, Komunikasi
Pemasaran, Edisi 1, Jakarta: Kencana.

Magid, L. (2014). "Google Classroom Offers Assignment Center for Students and Teachers". Forbes.

McMulli \& Munroe (2004). "VMoodle at DCU".

Sclater, N. (2008). "A Large-scale Open Source eLearning Systems at the Open University". Educase.

Sugiyono (2004), Statistik Nonparametris untuk Penelitian, Bandung: Alfabeta.

Umar, Husein (2008), Desain Penelitian Akutansi Keperilakuan, Edisi 1, Jakarta: PT RajaGrafindo Persada. (2009), Metode Penelitian untuk Skripsi dan Tesis Bisnis, Edisi 2, Jakarta: PT.RajaGrafindo Persada.

West, Richard dan Lynn H. Turner (2008), Pengantar Teori Komunikasi, Edisi 3, Buku II, Terjemahan oleh Maria Natalia Damayanti Maer, Jakarta: Salemba Humanika. 